\title{
TARTU RADIOCARBON DATES XIII
}

\section{ARVI LIIVA}

Institute of Zoology and Botany, Estonian Academy of Sciences, Vanemuise Street 21 EE-2400 Tartu, Estonia

and

\section{ILZE LOZE}

Institute of Latvian History, 19 Turgenev Street, LV-1518 Riga, Latvia

\section{INTRODUCTION}

This date list reports dates of archaeological samples of Mesolithic and Neolithic sites of Estonia, Latvia and Lithuania. We use liquid scintillation counting at the Geochemical and Statistical Laboratory of the Institute of Zoology and Botany, Estonian Academy of Sciences. Our modern standard is benzene enriched in ${ }^{14} \mathrm{C}$ and its activity is checked with an NBS oxalic acid standard sample. Dates are given in conventional ${ }^{14} \mathrm{C}$ years, based on the Libby half-life of $5570 \pm 30 \mathrm{yr}$. $\mathrm{AD} 1950$ is the reference year. Errors are based on one standard deviation calculated from count rates.

\section{LATVIA}

\section{Lubāna lowland sites series}

The Lubāna lowland is in eastern Latvia, $200 \mathrm{~km}$ east of Riga. Samples were collected by I. Loze and A. Liiva. Geomorphological and geological studies were made by G. Eberhards. Archaeological excavations of the Piestina site were conducted by I. Loze and F. Zagorskis.

\section{Early Mesolithic}

TA-1317. Sūlagals

$9575 \pm 80$

Wood from depth $116-126 \mathrm{~cm}$.

Middle Mesolithic

TA-1611. Zvidze

$7240 \pm 100$

Wood from depth 190-198 cm.

TA-857. Zvidze

$7370 \pm 90$

Peat with charcoal, wood and nutshells from depth $166-170 \mathrm{~cm}$.

\section{Late Mesolithic}

TA-1612. Zvidze

$6610 \pm 80$

Wood from depth 170-190 cm. 
TA-1607. Zvidze

$6630 \pm 80$

Wooden pole from depth $170-180 \mathrm{~cm}$.

TA-856. Zvidze

$6770 \pm 60$

Charcoal from depth $90-120 \mathrm{~cm}$.

TA-861. Zvidze

$6780 \pm 60$

Wood from depth $130 \mathrm{~cm}$.

TA-851. Zvidze

$7020 \pm 60$

Charcoal from depth $160-180 \mathrm{~cm}$.

TA-864. Zvidze

$7020 \pm 60$

Wood from depth $155 \mathrm{~cm}$.

TA-1632. Zvidze

$7060 \pm 80$

Wood from depth 180-190 cm.

TA-863. Zvidze

$7110 \pm 60$

Peat from depth $150 \mathrm{~cm}$.

TA-1820. Osa

$6710 \pm 80$

Wood from depth 130-160 cm.

Early Neolithic

TA-1594. Zvidze

$5440 \pm 80$

Wood from depth $108-120 \mathrm{~cm}$.

TA-1818. Zvidze

$5770 \pm 60$

Wood from depth 140-150 cm.

TA-1819. Zvidze

$5870 \pm 60$

Charcoal from depth $140-150 \mathrm{~cm}$.

TA-1608. Zvidze

$6110 \pm 80$

Wood from depth $135-140 \mathrm{~cm}$.

TA-1592. Zvidze

$6170 \pm 70$

Wood from depth $120-125 \mathrm{~cm}$. 
TA-1593. Zvidze

$6210 \pm 80$

Charcoal from depth $125-135 \mathrm{~cm}$.

TA-1609. Zvidze $6210 \pm 80$

Wood from depth $140-150 \mathrm{~cm}$.

TA-883. Zvidze

Wood from depth $112 \mathrm{~cm}$.

TA-852. Zvidze

$6315 \pm 60$

Charcoal from depth $75-85 \mathrm{~cm}$.

TA-862. Zvidze

$6535 \pm 60$

Wooden pole from depth $140 \mathrm{~cm}$.

TA-395. Zvejsalas

$4905 \pm 70$

Wood from depth 90-100 cm.

Middle Neolithic

TA-675. Zvidze

$4370 \pm 80$

Wood from depth $53 \mathrm{~cm}$.

TA-674. Zvidze

$4540 \pm 60$

Wood from depth $60 \mathrm{~cm}$.

TA-2253. Nainiekste

$4270 \pm 60$

Peat from depth $30-35 \mathrm{~cm}$.

TA-2254. Nainiekste

$4470 \pm 60$

Peat from depth $35-40 \mathrm{~cm}$.

TA-2255. Nainiekste

$4960 \pm 90$

Peat from depth $35-40 \mathrm{~cm}$.

$4100 \pm 100$

TA-2251. Piestina

Peat from depth $30-45 \mathrm{~cm}$.

TA-2252. Piestina

$4490 \pm 60$

Peat from depth $50-60 \mathrm{~cm}$. 
Late Neolithic

TA-382. Lagaža

$3640 \pm 70$

Wooden pole from depth $75-95 \mathrm{~cm}$.

TA-396. Lagaža

$3640 \pm 70$

Wooden pole from depth $75-95 \mathrm{~cm}$.

TA-749. Lagaža

$3685 \pm 80$

Wooden pole from depth $80-100 \mathrm{~cm}$.

TA-394. Abora I

$3770 \pm 60$

Wooden pole from depth $98 \mathrm{~cm}$.

TA-2145. Abora I

$4250 \pm 100$

Charcoal from depth 54-74 cm.

TA-2144. Abora I

$4490 \pm 80$

Charcoal from depth 90-115 cm.

TA-2143. I'a

$4120 \pm 90$

Wooden pole from depth $95 \mathrm{~cm}$.

TA-2249. Ǐca

$4260 \pm 70$

Wood from depth $90 \mathrm{~cm}$.

TA-2247. İa

$4390 \pm 80$

Wood from depth 90-95 cm.

TA-2248. Ǐ̌a

$4420 \pm 80$

Wood from depth $85-90 \mathrm{~cm}$.

TA-2250. Eini

$4735 \pm 60$

Peat from depth 90-105 cm.

\section{Zvidze site series}

The Zvidze habitation site is located in the western part of the Lake Lubāna hollow, northwest of the lake, on the edge of a wavy moraine leading into the Lubāna peaty hollow. The area is filled with lake deposits and covered with peat. Lake clay covers eroded areas of lake terraces and is gradually replaced by aleurites and sand. Overlying the clay are 1.3 to $1.5-\mathrm{m}$-thick yellow and gray sapropels. The site was investigated in 1973-1975 and 1981-1984. Samples were collected in 1982 
by I. Loze and M. Ruša. G. Eberhards studied the geomorphology and I. Jakubovska and V. Stelle the palynology of the site.

TA-2033. Zvidze

$4580 \pm 80$

Peat from depth $35-40 \mathrm{~cm}$. Pollen Zone SB2.

TA-1802. Zvidze.

$4430 \pm 50$

Peat from depth $40-45 \mathrm{~cm}$. Pollen Zone SB2.

TA-1801. Zvidze

$4750 \pm 60$

Peat from depth 50-55 cm. Pollen Zone SB1.

TA-1800. Zvidze

$\mathbf{5 3 2 0} \pm \mathbf{5 0}$

Peat from depth 70-75 cm. Pollen Zone AT2.

TA-1799. Zvidze

$5510 \pm 70$

Peat from depth 75-80 cm. Pollen Zone AT2.

TA-1798. Zvidze

$6050 \pm 100$

Peat from depth 100-105 cm. Pollen Zone AT2.

TA-1782. Zvidze

$5990 \pm 60$

Peat from depth $115-120 \mathrm{~cm}$. Pollen Zone AT2.

TA-1746. Zvidze

$6350 \pm 60$

Peat from depth 130-135 cm. Pollen Zone AT2.

TA-1745. Zvidze

$7480 \pm 80$

Peat with charcoal from depth $140-145 \mathrm{~cm}$. Pollen Zone AT1.

TA-1723. Zvidze

$7180 \pm 100$

Sapropel from depth $145-147 \mathrm{~cm}$. Pollen Zone AT1.

TA-1722. Zvidze

$7650 \pm 100$

Sapropel from depth 150-155 cm. Pollen Zone BO2.

\section{ESTONIA}

\section{Kääpa site series}

The Kääpa habitation site is located on the left bank of the Vihandu River. The 50-cm-thick cultural level was at a depth of $160 \mathrm{~cm}$ in peat. The habitation site was investigated in 1959 and 1962. 
TA-747. Kääpa

$3460 \pm 80$

Wood from depth $80 \mathrm{~cm}$.

TA-815. Kääpa

$4640 \pm 100$

Peat from depth $40-48 \mathrm{~cm}$.

TA-724. Kääpa

$4740 \pm 60$

Wood from depth $160-210 \mathrm{~cm}$.

TA-748. Kääpa

$4760 \pm 80$

Wood from depth 60-65 cm.

\section{LITHUANIA}

The Šventoji 1A and 1B habitation sites are located in northwestern Lithuania, at the lagoon of the Baltic Sea, $10 \mathrm{~km}$ north of Palanga. They were investigated by R. Rimantiene in 1966-1972.

TA-246. Šventoji 1A

TA-247. Šventoji 1B
$4120 \pm 80$

$4400 \pm 90$

\section{REFERENCES}

Liiva, A. and Loze, I. 1988 Radiocarbon dates of the Early Neolithic in the eastern Baltic. Isotope-Geochemical Research in the Baltic and Belorussia. Tallinn: 106-166 (in Russian).

Loze, I. and Liiva, A. 1989a Results of radiocarbon dates of archaeological sites in the Lubana district in Latvia. Geochronology of the Quaternary. Tallinn: 105 (in Russian).

Loze, I. and Liiva, A. 1989b Chronology of the Early Neolithic in the Eastern Baltic. Proceedings of the Latvian SSR Academy of Sciences 2(499): 50-67 (in Russian).

1990 Radiocarbon dates of the Mesolithic of the Eastern Baltic. Proceedings of the Latvian SSR Academy of Sciences 10(519): 78-85. 